\title{
Pengaruh Model Siklus Belajar 5E (Engagement, Exploration, Explanation, Elaboration, Evaluation) terhadap Kemampuan Berpikir Kritis dan Penguasaan Konsep IPA
}

\author{
N.L Superni ${ }^{1 *}$, Nyoman Dantes ${ }^{2}$, I M Gunamantha ${ }^{3}$ \\ 1,2,3 Program Studi Pendidikan Dasar, Program Pascasarjana Universitas Pendidikan Ganesha Singaraja, Indonesia
}

ARTICLEINFO

Article history:

Received 21 November 2017

Received in revised form

12 Desember 2017

Accepted 15 Januari 2018

Available online 20

Februari 2018

\section{Kata Kunci:}

berpikir kritis, penguasaan

konsep IPA, siklus belajar $5 E$

\section{Keywords:}

critical thinking, mastery of

science concept, learning cycle $5 E$

\begin{abstract}
A B S TRAK
Penelitian ini bertujuan untuk mengetahui pengaruh model siklus belajar $5 \mathrm{E}$ terhadap kemampuan berpikir kritis dan penguasaan konsep IPA siswa kelas V Sekolah Dasar Gugus VII Kecamatan Kubutambahan. Penelitian ini menggunakan pendekatan eksperimen semu dengan rancangan Single Factor Independent Groups Design. Populasi dalam penelitian sebanyak 137 orang siswa. Sampel penelitian berjumlah 44 siswa ditentukan dengan teknik random sampling. Data berpikir kritis siswa dikumpulkan dengan tes uraian, dan data penguasaan konsep IPA siswa dikumpulkan dengan tes pilihan ganda. Data dianalisis menggunakan MANOVA berbantuan SPSS 16.00 for windows. Hasil Penelitian menunjukkan bahwa: pertama, kemampuan berpikir kritis siswa yang mengikuti model siklus belajar $5 \mathrm{E}$ secara signifikan lebih baik daripada siswa yang mengikuti model pembelajaran konvensional $(F=7,055 ; p<0,05)$; kedua, penguasaan konsep IPA siswa yang mengikuti model siklus belajar $5 \mathrm{E}$ secara signifikan lebih baik daripada siswa yang mengikuti model pembelajaran konvensional $(F=13,219 ; p<0,05)$; ketiga, secara simultan kemampuan berpikir kritis dan penguasaan konsep IPA antara siswa yang mengikuti model siklus belajar 5E secara signifikan lebih baik daripada siswa yang mengikuti model pembelajaran konvensional $(F=7,440 ; p<0,05)$. Model konvensional yang digunakan dalam penelitian ini adalah metode ceramah.
\end{abstract}

\section{A B S T R A C T}

This study was aimed at finding out the effect of learning cycle $5 \mathrm{E}$ model on the ability of critical thinking and mastery of science concept the fifth grade students of elementary school Cluster VII Kubutambahan district. This study used a quasi-experiment design with Single Factor Independent Groups Design. The population consisted of 137 students. The sample was 44 students determined by random sampling technique. The data on the student's critical thinking were collected with a test description, and the data on the students mastery of science concept were collected with a multiple choice test. The data were analyzed using MANOVA aided with SPSS 16.00 for windows. The results showed that, first, the students critical thinking skills following the learning cycle $5 \mathrm{E}$ model was significantly better than that of those who joined conventional teaching model $(F=7.055 ; p<0.05)$; secondly, the mastery of science concept following the learning cycle $5 \mathrm{E}$ model was significantly better than that of those who joined conventional teaching model $(F=13.219 ; p<0.05)$; third, simultaneously critical thinking ability and mastery of science concept among students who follow learning cycle $5 \mathrm{E}$ model significantly better than that of those who joined conventional teaching model $(F=7,440 ; p<0,05)$. The conventional model used in this research is the lecture method.

\footnotetext{
* Corresponding author.

E-mail addresses: luh.superni@pasca.undiksha.ac.id (Luh Superni)
} 


\section{Pendahuluan}

Pendidikan memiliki peran penting dalam upaya peningkatan sumber daya manusia ke arah yang lebih baik. Pendidikan diharapkan mampu membentuk peserta didik yang dapat mengembangkan sikap, keterampilan dan kecerdasan intelektualnya agar menjadi manusia yang terampil, cerdas serta berakhlak mulia. Membekali peserta didik agar cerdas secara intelektual pengetahuan dan sosial merupakan peran pendidik dalam proses keberlangsungan kegiatan belajar mengajar. Ilmu Pengetahuan Alam (IPA) adalah salah satu mata pelajaran yang sangat penting. Suastra (2009:11) menyatakan bahwa, di sekolah dasar mata pelajaran IPA menjadi pondasi dasar bagi siswa nantinya dalam mengikuti mata pelajaran Sains di SMP maupun SMA. Upaya untuk meningkatkan kualitas pendidikan IPA adalah dengan meningkatkan kemampuan berpikir kritis dalam pembelajaran IPA.

Berpikir kritis adalah proses disiplin secara intelektual dimana seseorang secara aktif dan terampil memahami, mengaplikasikan, menganalisis, mensintesakan, memutuskan dan/atau mengevaluasi berbagai informasi yang dikumpulkan atau yang di ambil dari pengalaman (observasi), dari refleksi yang dilakukannya, dari penalaran, atau dari komunikasi yang dilakukan Paul (dalam Sihotang, 2012). Dari pengertian tersebut, dapat diartikan bahwa orang yang berpikir kritis akan mampu memanfaatkan potensi yang ada dalam dirinya. Selain itu, orang yang berpikir kritis akan cepat mengidentifikasi informasi yang relevan dan mampu mengambil keputusan. Pada kenyataannya, kemampuan berpikir kritis peserta didik belum dikembangkan terutama di sekolah dasar. Hal ini terlihat pada rancangan, pelaksanaan, dan penilaian pembelajaran di sekolah dasar belum ditujukan pada pengembangan kemampuan berpikir kritis peserta didik. Karakteristik pembelajaran di sekolah dasar masih bersifat konvensional dan dalam pelaksanannya masih didominasi oleh guru (teacher-centered) sehingga pendekatan pembelajaran yang berpusat pada siswa (student-centered) belum terintegrasi penuh dalam pelaksanaan pembelajaran di kelas.

Selain berpikir kritis, penguasaan konsep juga penting pada mata pelajaran IPA. Penguasaan konsep yang baik akan membuat peserta didik dapat berpikir pada tingkatan yang lebih tinggi lagi. Penguasaan konsep IPA adalah suatu kemampuan menemukan ide abstrak dalam pembelajaran IPA untuk mengklasifikasi objek-objek yang biasanya dinyatakan dalam suatu istilah kemudian dituangkan ke dalam contoh, sehingga seseorang dapat mengerti/memahami suatu konsep dengan jelas. Seseorang yang menguasai konsep dapat digolongkan dan memiliki keterampilan untuk mengaplikasikannya dalam IPA dan dunia sekitarnya.

Pembelajaran konvensional mengacu pada teori belajar behavioristik. Teori behavioristik kurang memberikan kesempatan kepada peserta didik untuk menggali sendiri pengetahuannya sehingga belajar dilihat sebagai proses meniru. Pengaruh model pembelajaran konvensional dalam pembelajaran IPA cenderung berorientasi pada materi yang tercantum dalam kurikulum dan buku teks. Pada saat guru menjelaskan materi, siswa cenderung apatis mendengarkan, apa yang dijelaskan pendidik. Siswa tidak dapat mengargumentasikan, jika ada hal-hal yang ingin ditanyakan terkait dengan materi yang terdapat dalam buku siswa.

Fenomena ini juga terjadi di sekolah tempat peneliti melakukan penelitian. Proses pembelajaran yang dilakukan masih menggunakan metode ceramah. Kegiatan pembelajaran masih bersifat teacher center. Materi yang diberikan adalah materi yang sudah jadi sehingga tidak menuntut siswa untuk berpikir ulang. Akibat dari pembelajaran tersebut peserta didik menjadi terbiasa menerima apa saja yang diberikan oleh pendidik tanpa mau berusaha menemukan sendiri konsep-konsep yang sedang dipelajari.

Menyadari banyaknya permasalahan dalam pembelajaran, maka perlu adanya suatu pembaharuan. Salah satu pembaharuan tersebut adalah memodifikasi proses pembelajaran dengan menggunakan model pembelajaran yang inovatif. Salah satunya dengan menerapkan model pembelajaran siklus belajar 5E. Marhaeni (2013) menyatakan bahwa model pembelajaran adalah bentuk pembelajaran yang tergambar dalam proses pembelajaran yang disajikan secara khas oleh guru di kelas. Model siklus belajar adalah model pembelajaran yang memungkinkan peserta didik menemukan konsep sendiri atau memantapkan konsep yang dipelajari,mencegah terjadinya kesalahan konsep, dan memberikan peluang kepada peserta didik menerapkan konsep-konsep yang telah dipelajari pada situasi baru Soebagio, dkk (2001). Di awal pengembangannya sintaks model pembelajaran siklus belajar menurut Thomas (2003) terdiri dari tiga tahap yaitu exploration, concept introduction dan concept application. Anthony(2002) mengembangkannya menjadi lima tahap yang dikenal dengan nama 5E (engagement, exploration, explanation, elaboration, dan evaluation).

Pada tahap engagement, guru berusaha membangkitkan minat dengan keingintahuan (curiocity) peserta didik tentang topik yang akan diajarkan. Tahap exploration, peserta didik diberi kegiatan yang dapat melibatkan keaktifannya untuk menguji prediksi dan hipotesis melalui alternatif yang diambil, mencatat hasil pengamatan dan mendiskusikan dengan peserta didik lain serta bekerja sama dalam 
kelompok-kelompok kecil tanpa pengajaran langsung dari guru. Pada tahap explanation, guru dituntut mendorong siswa untuk menjelaskan suatu konsep dengan kalimat/kata-kata sendiri, meminta bukti dan klarifikasi atas penjelasan siswa, dan saling mendengar secara kritis penjelasan antar siswa. Pada tahap elaboration, guru memberikan klarifikasi atas gagasan siswa yang masih bersifat miskonsepsi dan memberi kesempatan kepada siswa untuk membuat jalinan konsep dalam struktur kongnitifnya dengan cara mengaitkan atau mengembangkan konsep-konsep dan keterampilan-keterampilan yang diperolehnya. Tahap akhir model siklus belajar 5E adalah evaluation. Pada tahap ini, peserta didik diberi pertanyaan untuk mendiagnosis pelaksanaan kegiatan belajar dan mengetahui pemahaman peserta didik mengenai konsep yang diperoleh.

Hasil penelitian yang dilakukan oleh Arini, dkk.(2017) menunjukkan bahwa penerapan model pembelajaran Learning Cycl 5E dapat meningkatkan kemampuan berpikir kritis dan prestasi belajar siswa. Demikian pula penelitian yang dilakukan oleh Yuliati (2015) menunjukkan bahwa penerapan model Learning Cycle 5E dapat meningkatkan pembelajaran IPA. Sejalan dengan penelitian yang dilakukan oleh Nugraheni (2017) hasil penelitian menunjukkan bahwa siklus belajar 5E berpengaruh terhadap kemampuan literasi sains dan hasil belajar siswa.

Bertolak dari hal tersebut penelitian ini bertujuan untuk menganalisis dan mendeskripsikan : 1) Perbedaan kemampuan berpikir kritis antara siswa yang mengikuti pembelajaran dengan model siklus belajar 5E dengan siswa yang mengikuti model pembelajaran konvensional pada mata pelajaran IPA siswa kelas V Gugus VII Kecamatan Kubutambahan, 2) Perbedaan penguasaan konsep IPA antara siswa yang mengikuti model siklus belajar 5E dengan siswa yang mengikuti model pembelajaran konvensional pada mata pelajaran IPA siswa kelas V Gugus VII Kecamatan Kubutambahan, dan 3) Perbedaan kemampuan berpikir kritis dan penguasaan konsep IPA secara simultan antara siswa yang mengikuti pembelajaran dengan model siklus belajar 5E dengan siswa yang mengikuti model pembelajaran konvensional pada mata pelajaran IPA siswa kelas V Gugus VII Kecamatan Kubutambahan

\section{Metode}

Penelitian ini dilaksanakan di Gugus VII Kecamatan Kubutambahan Tahun Pelajaran 2017/2018. Jenis penelitian ini adalah eksperimen semu (quasy exsperiment) dengan rancangan single factor independent group design dengan menggunakan kelompok eksperimen (model siklus belajar 5E) dan kelompok kontrol (model pembelajaran konvesional). Populasi dalam penelitian ini adalah seluruh siswa kelas V Gugus VII Kecamatan Kubutambahan. Teknik pengambilan sampel dengan random sampling.

Hasil pemilihan sampel menetapkan kelas V SD N 4 Bontihing dengan siswa sejumlah 26 orang sebagai kelompok eksperimen dan kelas V SD N 1 Bontihing dengan siswa sebanyak 18 orang sebagai kelompok control. Variabel bebas dalam penelitian ini berupa model siklus belajar 5E dan model pembelajaran konvensional sedangkan variabel terikatnya berupa kemampuan berpikir kritis dan penguasaan konsep IPA. Teknik pengumpulan data yang digunakan dalam penelitian ini adalah teknik tes uraian untuk kemampuan berpikir kritis dengan menggunakan skala Likert yang memuat empat pilihan jawaban dengan bentuk data interval dan tes pilihan ganda untuk penguasaan konsep IPA. Analisis data yang digunakan pada penelitian ini analisis statistik deskriptif, yang artinya bahwa data dianalisis dengan menghitung nilai rata-rata, median, standar deviasi, varian, skor maksimum, dan skor minimum. Teknik yang digunakan untuk menganalisis data guna menguji hipotesis penelitian adalah MANOVA. Sebelum dilakukan analisis data, maka dilakukan uji normalitas sebaran data dengan menggunakan uji Kolmogorov-smimov, uji homogenitas varians dengan uji Levene's, dan uji korelasi antar variabel terikat (kolonieritas) dengan menggunakan pearson's product moment.

\section{Hasil dan pembahasan}

Adapun hasil analisis data statistik deskriptif disajikan pada Tabel 1.

Tabel 1. Rekapitulasi Hasil Perhitungan tentang Kemampuan Berpikir Kritis dan Penguasaan Konsep IPA Kelompok Siswa yang Mengikuti Moel Siklus Belajar 5E dan Kelompok yang Mengikuti Model Pembelajaran Konvensional

\begin{tabular}{lcccc}
\hline Statistik & \multicolumn{3}{c}{ Variabel } \\
\cline { 2 - 5 } & A1Y1 & A2Y1 & A1Y2 & A2Y2 \\
\hline Mean & 59,31 & 55,50 & 22,85 & 20,33 \\
Median & 58,00 & 55,00 & 22,50 & 20,00 \\
Standar Deviasi & 4,96 & 4,22 & 2,19 & 2,35 \\
\hline
\end{tabular}




\begin{tabular}{lcccc}
\hline Varians & 24,62 & 17,79 & 4,78 & 5,53 \\
Skor Minimum & 52 & 49 & 20 & 17 \\
Skor Maksimum & 68 & 64 & 27 & 25 \\
Jangkauan/Rentangan & 17,00 & 15,00 & 7,00 & 8,00 \\
\hline
\end{tabular}

Data kemampuan berpikir kritis siswa yang mengikuti pembelajaran dengan model siklus belajar 5E (A1Y1) menunjukkan skor minimal 52, skor maksimal 68, rentangan 16, rata-rata (mean) sebesar 59,31, standar deviasi sebesar 4,96, modus sebesar 145, dan median sebesar 149,00. Untuk mendapatkan gambaran yang lebih jelas, kemampuan berpikir kritis siswa yang mengikuti model siklus belajar 5E dapat digambarkan pada gambar 1.

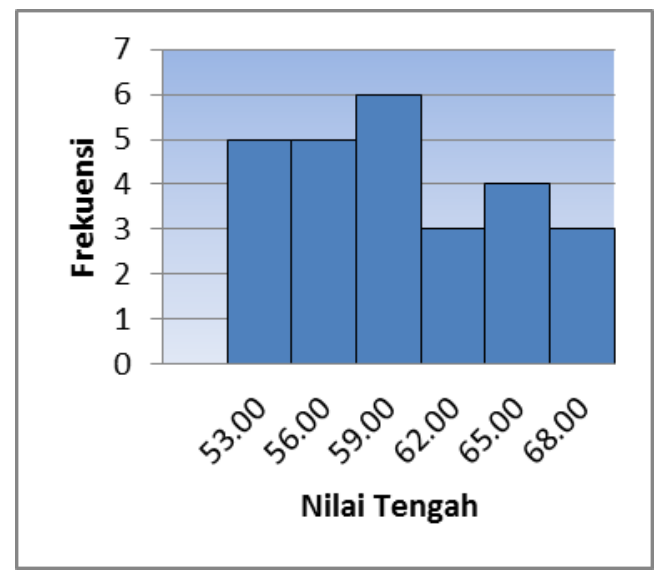

Gambar 1. Histogram Data Kemampuan Berpikir Kritis Siswa yang Mengikuti Model Pembelajaran Siklus Belajar 5E (A1Y1)

Data tentang kemampuan berpikir kritis yang mengikuti pembelajaran dengan model pembelajaran konvensional mempunyai rentangan $=15, \mathrm{n}=18$, skor minimum $=49$, skor maksimum $=64$, banyak kelas interval $=6$, panjang kelas interval $=3$, rata-rata $=55,5$, median $=55$, standar deviasi $=4,22$, dan varians $=$ 17,79. Distribusi frekuensi data pembelajaran dengan model pembelajaran konvensional disajikan dalam gambar 2.

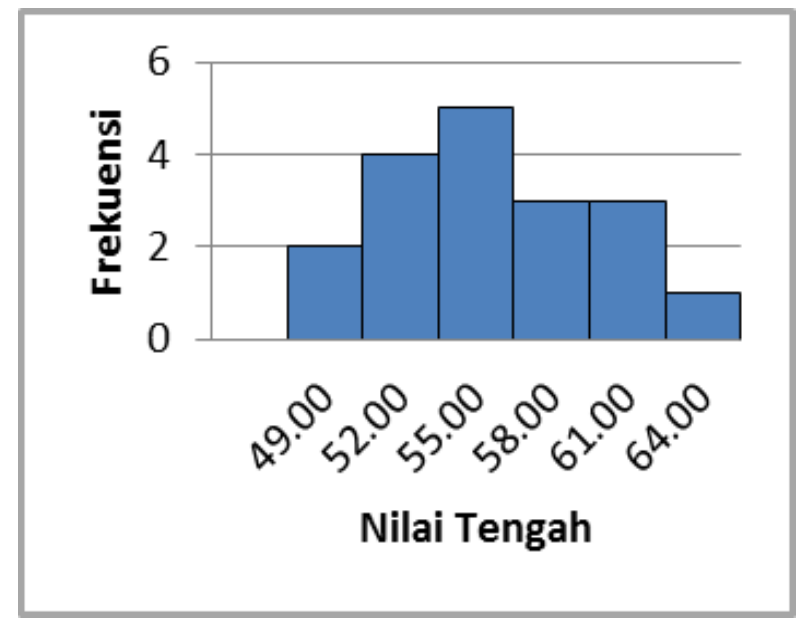

Gambar 2. Histogram Kemampuan Berpikir Kritis Siswa yang Mengikuti Model Pembelajaran Konvensional (A2Y1)

Berdasarkan pada hasil perhitungan di atas, dapat disimpulkan bahwa Kemampuan Berpikir Kritis Siswa yang Mengikuti Model Konvensional termasuk pada kategori "tinggi". Data tentang penguasaan konsep IPA yang mengikuti pembelajaran dengan model pembelajaran siklus belajar 5E mempunyai rentangan $=7, \mathrm{n}=26$, skor minimum $=20$, skor maksimum $=27$, banyak kelas interval $=4$, panjang kelas interval $=2$, rata-rata $=22,85$, median $=22,5$, standar deviasi $=2,19$, dan varians $=4,78$. Distribusi frekuensi data penguasaan konsep IPA disajikan dalam Gambar 3. 


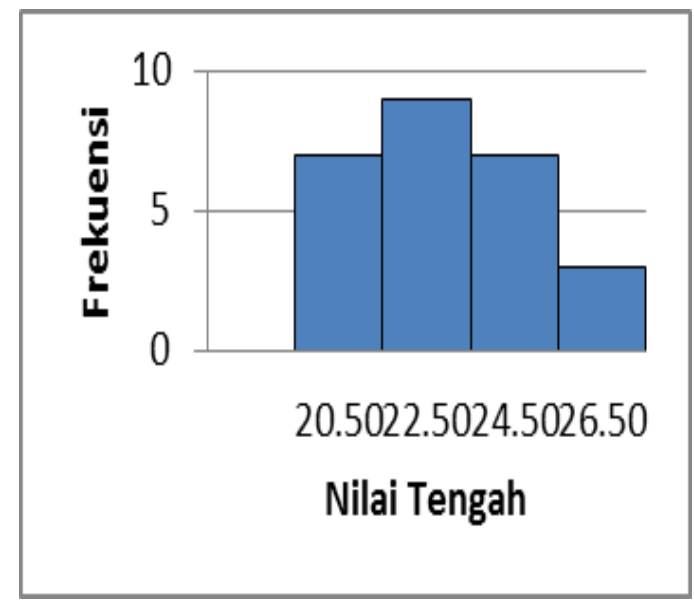

Gambar 3. Histogram Penguasaan Konsep IPA Siswa yang Mengikuti Model Pembelajaran Siklus Belajar 5E (A1Y2)

Berdasarkan pada hasil perhitungan di atas, dapat disimpulkan bahwa Penguasaan Konsep IPA Siswa Yang Mengikuti Model Siklus Belajar 5E termasuk pada kategori “ sangat tinggi”.

Data tentang penguasaan konsep IPA yang mengikuti pembelajaran dengan model pembelajaran konvensional mempunyai rentangan $=8, \mathrm{n}=18$, skor minimum $=17$, skor maksimum $=25$, banyak kelas interval $=5$, panjang kelas interval $=2$, rata-rata $=20,33$, median $=20$, standar deviasi $=2,35$, dan varians $=5,53$. Distribusi frekuensi data pembelajaran dengan model pembelajaran konvensional disajikan dalam Gambar 4.

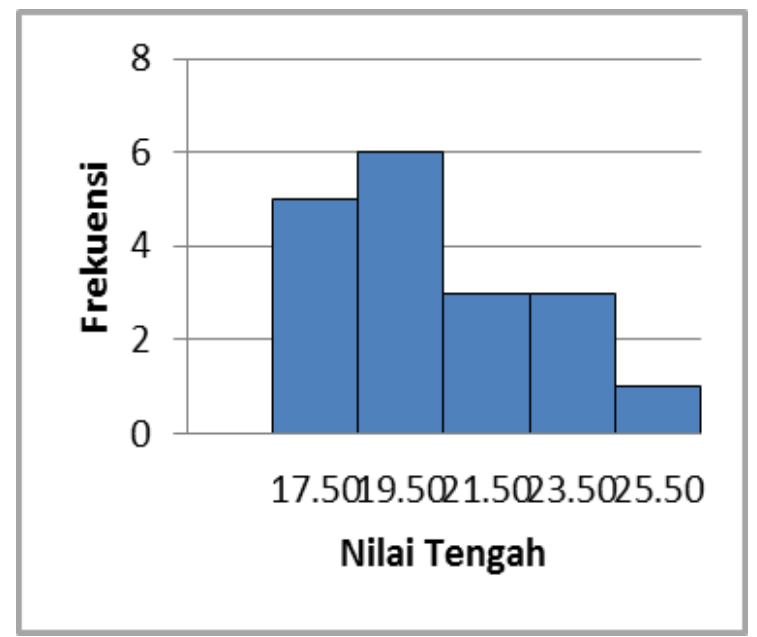

Gambar 4. Histogram Penguasaan Konsep IPA Siswa yang Mengikuti Model Pembelajaran Konvensional (A2Y2)

Berdasarkan pada hasil perhitungan di atas, dapat disimpulkan bahwa Penguasaan Konsep IPA siswa yang mengikuti Model Pembelajaran Konvensional termasuk pada kategori "tinggi". Berdasarkan hasil analisis diketahui bahwa kencederungan data kemampuan berpikir kritis siswa yang mengikuti model pembelajaran siklus belajar 5E dengan rerata $=59,31$ dan yang megikuti model pembelajaran konvensional dengan rerata $=55,50$ masuk dalam kategori tinggi. Walaupun berada pada kategori yang sama, dilihat dari rerata nilai kemampuan berpikir kritis yang diperoleh siswa dapat disimpulkan bahwa kemampuan berpikir kritis siswa yang mengikuti model pembelajaran siklus belajar 5E lebih baik daripada kemampuan berpikir kritis siswa yang mengikuti pembelajaran dengan model pembelajaran konvensional.

Pengujian hipotesis pertama, hipotesis nul ditolak dan hipotesis alternatif diterima. Ini berarti terdapat perbedaan kemampuan berpikir kritis yang signifikan antara kelompok siswa yang 
menggunakan model pembelajaran siklus belajar 5E dengan kelompok siswa yang menggunakan model pembelajaran konvensional. Penelitian yang mendukung penelitian ini adalah Permatasari (2016) yang menyatakan bahwa peningkatan yang terjadi pada kelas eksperimen lebih baik dibandingkan kelas kontrol. Penelitian lain yang mendukung temuan ini adalah penelitian yang dilakukan oleh Arini, dkk (2017). Hasil penelitian menunjukkan bahwa penerapan model pembelajaran Learning Cycle 5E dapat meningkatkan kemampuan berpikir kritis dan prestasi belajar siswa.

Berdasarkan hasil analisis, diketahui bahwa kecenderungan data penguasaan konsep IPA siswa yang mengikuti model pembelajaran siklus belajar $5 \mathrm{E}$ dengan rerata $=22,85$ masuk dalam kategori sangat tinggi. Sementara penguasaan konsep IPA siswa yang megikuti pembelajaran dengan model pembelajaran konvensional dengan rerata $=20,33$ masuk dalam kategori tinggi. Maka, dapat disimpulkan kecenderungan data penguasaan konsep IPA yang mengikuti model pembelajaran siklus belajar 5E lebih baik daripada penguasaan konsep IPA siswa yang mengikuti pembelajaran dengan model pembelajaran konvensional.

Pengujian hipotesis kedua, hipotesis nul ditolak dan hipotesis alternatif diterima. Ini berarti terdapat perbedaan penguasaan konsep IPA yang signifikan antara kelompok siswa yang menggunakan model pembelajaran siklus belajar 5E dengan kelompok siswa yang menggunakan model pembelajaran konvensional. Temuan penelitian di atas sejalan dengan penelitian yang dilakukan Mardiana, dkk (2015). Dari hasil penelitian menunjukkan bahwa terdapat perbedaan hasil belajar yang signifikan antara kelas yang menerapkan model pembelajaran learning cycle (5E) dengan kelas yang menerapkan model pembelajaran two stay two stray. Penelitian lain yang mendukung temuan ini adalah penelitian yang dilakukan oleh Aslindawaty (2017). Hasil penelitian menunjukkan bahwa melalui model pembelajaran learning cycle 5E (engagement, exploration, explanation, elaboration, evaluation) dapat meningkatkan hasil belajar siswa.

Berdasarkan hasil temuan dalam penelitian ini yang menunjukan bahwa nilai F untuk Pillai's Trace, Wilks' Lambda, Hotelling's Trace, dan Roy's Largest Root memiliki nilai signifikansi lebih kecil daridapa 0,05. Maka dari itu, harga F untuk Pillai's Trace, Wilks' Lambda, Hotelling's Trace, dan Roy's Largest Root signifikan. Jadi, dapat disimpulkan bahwa terdapat perbedaan penguasaan konsep IPA dan kemampuan berpikir kritis yang signifikan antara kelompok siswa yang menggunakan model pembelajaran siklus belajar 5E dengan kelompok siswa yang menggunakan model pembelajaran konvensional. Pengujian hipotesis ketiga, hipotesis nul ditolak dan hipotesis alternatif diterima. Ini berarti terdapat perbedaan penguasaan konsep IPA dan kemampuan berpikir kritis yang signifikan antara kelompok siswa yang menggunakan model pembelajaran siklus belajar 5E dengan kelompok siswa yang menggunakan model pembelajaran konvensional.

Temuan penelitian ini didukung oleh penelitian Sulwan (2016). Hasil penelitian disimpulkan bahwa peningkatan berpikir kritis dengan model siklus belajar 5E yang terjadi pada kelas eksperimen lebih baik dibandingkan kelas control. Penelitian lain yang mendukung temuan ini adalah penelitian yang dilakukan oleh Cahyani, dkk (2016). Hasil penelitian menunjukkan bahwa Penguasaan konsep siswa yang dibelajarkan dengan model pembelajaran Learning Cycle 5E lebih tinggi daripada penguasaan konsep siswa yang dibelajarkan dengan metode konvensional. Hasil ini sekaligus menunjukkan bahwa keterampilan berpikir kritis dan penguasaan konsep IPA Siswa yang mengikuti pembelajaran dengan model siklus belajar 5E lebih baik dari kelompok siswa yang mengikuti pembelajaran dengan model pembelajaran konvensional. Pembelajaran konvensional lebih menekankan pada penyampaian informasi yang bersumber dari buku teks, referensi, atau pengalaman pribadi dengan menggunakan teknik ceramah maupun diskusi, sehingga pengetahuan yang akan dipelajari siswa harus disajikan oleh guru perlu memberikan definisi dari konsep yang akan diterima siswa. Ini berdampak pada kualitas pencapaian tujuan belajar yang telah ditetapkan relatif rendah karena guru sering hanya mengejar target waktu untuk menghabiskan target materi pelajaran.

Pada model pembelajaran siklus belajar 5E, siswa dapat mengidentifikasi suatu pola keteraturan pada fenomena yang diselidiki, memperkenalkan konsep-konsep yang ada hubungannya dengan fenomena yang diselidiki dan mendiskusikannya dalam konteks apa yang telah diamati, kemudian menggunakan konsep-konsep tersebut pada situasi baru. Pembelajaran yang masih cenderung berpusat pada guru belum dapat melatih siswa dalam keterampilan berpikir kritisnya sehingga diperlukan model pembelajaran yang berpusat pada siswa melalui model pembelajaran yang berorientasi konstruktivistik, salah satunya model Siklus Belajar 5E (Lorsbach, 2002). Model siklus belajar 5E adalah suatu model pembelajaran yang berpusat pada siswa (student centered). Pembelajaran dengan model siklus belajar 5E siswa aktif bertanya, menjawab, mengerjakan soal ke depan, dan berdiskusi kelompok untuk memecahkan permasalahan dan menemukan konsep sendiri. 


\section{Simpulan dan saran}

Berdasarkan temuan di atas, dapat disimpulkan bahwa model siklus belajar $5 \mathrm{E}$ memberikan pengaruh yang signifikan terhadap kemampuan berpikir kritis dan penguasaan konsep IPA pada siswa kelas V Sekolah Dasar di Gugus VII Kecamatan Kubutambahan. Berdasarkan temuan-temuan yang telah dikemukakan di atas, adapun saran yang dapat diajukan dalam penelitian ini adalah sebagai berikut. Bagi Siswa, diharapkan selalu aktif berpikir kritis baik secara individu maupun kelompok dalam mengikuti mata pelajaran IPA maupun mata pelajaran lainnya. Pembelajaran dengan menggunakan model siklus belajar 5E dapat digunakan sebagai alternatif pembelajaran karena langkah-langkah pembelajaran dalam metode tersebut dapat melatih keterampilan berpikir kritis siswa dan di lengkapi dengan perangkat seperti lembar kerja siswa yang sesuai dengan tahapan untuk melatih keterampilan berpikir kritis. Siswa lebih sering dilibatkan dalam proses pembelajaran agar terbiasa dilatih keterampilan berpikir kritis. Bagi Guru, hendaknya memahami dan mengetahui permasalahan yang dihadapi siswa dalam proses pembelajaran, sehingga guru dapat memberikan solusi yang tepat untuk siswa. Guru diharapkan menerapkan model pembelajaran yang inovatif sehingga dapat meningkatkan kemampuan berpikir serta menguasai konsep pada pembelajaran IPA maupun pembelajaran yang lainnya. Dalam menerapkan siklus belajar, guru harus memperhatikan pengelolaan kelas agar pembelajaran dapat berjalan secara kondusif. Bagi Kepala Sekolah, hendaknya memberikan kebijakan-kebijakan dan kesempatan kepada guru menerapkan berbagai model pembelajaran yang sesuai dengan karakter peserta didik untuk meningkatkan prestasi belajar IPA. Menyediakan sarana dan prasarana yang dapat menunjang proses pembelajan baik itu di kelas maupun di luar kelas.

\section{Daftar Rujukan}

Arini,S. Haryono, dan Saputro, S. 2017. "Upaya Peningkatan Kemampuan Berpikir Kritis Dan Prestasi Belajar Siswa Dengan Menggunakan Model Pembelajaran Learning Cycle 5e Pada Materi Pokok Hidrolisis Garam Kelas Xi Mia 1 Sma Negeri 1 Banyudono Semester Genap Tahun Pelajaran 2015/2016". Jurnal Pendidikan Kimia. Program Studi Pendidikan Kimia Universitas Sebelas Maret Vol. 6 No. 2 Tahun 2017. Hal 161-170.

Aslindawaty, N. 2017. "Penerapan Model Pembelajaran Learning Cycle 5E (Enggagement, Exploration, Explanation, Elboration, Evaluation) untuk Mneingkatkan Hasil Belajar Ekonomi". Jurnal Office, Vol.3, No 1, 2017.

Cahyarini,A. Rahayu, S. dan Yahmin. 2016. “Pengaruh Model Pembelajaran Learning Cycle 5E Terhadap Penguasaan Konsep Siswa Pada Materi Asam Basa". Prosiding Seminar Nasional II. Universitas Muhammadiyah Malang. Tahun 2016

Candiasa. 2011. Statistik Multivariat Disertai Aplikasi SPSS. Singaraja:Universitas Pendidikan Ganesha

Dantes, N. 2012. Metode Penelitian. Yogyakarta: Andi.

Dantes. 2017. Desain Eksperimen Dan Analisis Data. Singaraja: Undiksha Press.

Lorsbach, A.W. 2009. The Learning Cycle as tool for planning Science Instruction. Illinois State University. Tersedia di http://coe.ilstu.edu/scienceed/lorsbach/257lrcy.htm (diakses tanggal 23 September 2015).

Mardiana, R. Yennita, dan Rahmad, M. 2015. “Implementasi Model Learning Cycle 5e Untuk Meningkatkan Pemahaman Konsep Fisika Pada Materi Fluida Statis Di Kelas X Sman Plus Propinsi Riau”. Journal Program Studi Pendidikan Fisika. Fakultas Keguruan dan Ilmu Pendidikan Universitas Riau. Tahun 2015.

Marhaeni, A.A.I.N. 2013. Landasan dan Inovasi Pembelajaran. Singaraja:Undiksha.

Nugraheni, D. 2017. “Pengaruh Siklus Belajar 5E Terhadap Kemampuan Literasi Sains Pada Materi Sistem Saraf Manusia". Jurnal Prodi Pendidikan Biologi. Vol 6 No 4 tahun 2017. Universitas Yogyakarta. 
Permatasari, D. Hairinda, dan Sartika, R.P. 2016. “Pengaruh Model Siklus Belajar 5E Terhadap Keterampilan Berpikir Kritis Siswa Pada Materi Koloid”. Artikel Penelitian Pendidikan Kimia, FKIP Universitas Tanjungpura Pontianak. Tahun 2016

Sanjaya, W. 2008. Strategi Pembelajaran Berorientasi Standar Proses Pendidikan. Jakarta:Kencana Prenada Media Group.

Sihotang, K. Rima, K.F, Molan, B. Ujan, A.A dan Ristyantoro, R. 2012. Critical Thinking. Jakarta: PT Pustaka Sinar Harapan.

Suastra, I.W. 2009. Pembelajaran Sains Terkini Mendekatkan Siswa dengan Lingkungan Alamiah dan Sosial Budaya. Singaraja: Universitas Pendidikan Ganesha.

Soebagio, Soetarno, dan Wiwik, H. (2001). Penggunaan Daur Belajar Untuk Peningkatan Kualitas Pembelajaran dan Pemahaman Konsep Sel Elektrolisis Pada Siswa Kelas III SMU Negeri 2 Jombang. Media Komunikasi Kimia. Jurnal Ilmu Kimia dan Pembelajarannya. 5 Pebruari 2001.

Sugiono, 2003. Statistika untuk Penelitian. Bandung:Alfabeta.

Sugiyono, 2009. Metode Penelitian Kuantitatif Kualitatif dan R \& D. Bandung:Alfabeta.

Sulwan. 2016. "Pengaruh Model Learning Cycle 5e Dan Gaya Kognitif Dalam Meningkatkan Pengetahuan Konseptual Hidrokarbon Dan Keterampilan Berpikir Kritis Siswa SMK". Jurnal Pendidikan Kimia. Program Pascasajana. Universitas Halu Oleo Kendari. Tahun 2016.

Suprijono, A. 2016. Model-model Pembelajaran Emansipatoris. Surabaya:Pustaka Pelajar.

Suryabrata, S. 2006. Metodologi Penelitian.Jakarta:Pt.Raja Grafindo Persasada.

Thomas, E.L. Conceptualizing A Learning Cycle Approach. The American Biology Teacher, 65(7), 518-522. Published by: National Association of Biolofy Teachers. Tersedia di: http://www.jstor.org/pss/4451551 (di-akses tanggal 23 September 3015).

Yuliati, Y. 2015. “ Penerapan Model Learning Cycle 5E Untuk Meningkatkan Pembelajaran IPA”. Jurnal Cakrawala Pendas, Volume I, No. 1 Januari 2015. 